ditioned power, to give him an absolute interest in the land, is apparently a vested limited interest. And that his option alone does not give him. ${ }^{20}$ However we may designate his interest in the land, we may not call that interest vested. It is at least no better than contingent until he has exercised his power. In this respect the position of the option-holder is not unlike that of the contingent remainderman in such a devise as : "Blackacre to $A$ for life, remainder to $B$ if $B$ marry," or indeed, "if B plant a rose bush on the testator's grave." Both $B$ and the option-holder must remain without a vested interest in the respective premises until a specified act has been done, a legal power exercised. The doing of that act, the exercise of that power, may be wholly within the sole volition of either; but until its exercise the interest does not vest. ${ }^{21}$

G. E. W.

\title{
ADVERSE POSSESSION OF ONE'S OWN DEBT
}

In a recent discussion in the Journal as to the effect of a new promise upon the running of the statute of limitations it was not necessary to determine whether a change in the statute affected only the remedy and hence did not run counter to constitutional objections. ${ }^{1}$ This vexed problem was presented in Gilbert v. Selleck (I919, Conn.) Io6 Atl. 439, where the Connecticut Supreme Court of Errors decided that the statute, in the case of a contract obligation, does not destroy the debt but merely takes away the remedy, and that one has no "property" in the bar of the statute, thus distinguishing a debt from realty or chattels where the "property" passes and both "legal title" and "real ownership" become vested by the running of the statute. The Court therefore held that even after the statute had run the legislature might provide an additional period during which suit could be brought upon.a contract of indemnity.

The only direct authority cited by the Court is the mooted case of Campbell v. Holt, ${ }^{2}$ decided by a bare majority in the United States Supreme Court. ${ }^{3}$ It is surprising that the opinion in the Connecticut case does not indicate how great is the divergence of opinion upon

\footnotetext{
${ }^{2}$ But might not a leasehold interest be such a "vested limited interest," so as to bring the lessee with option to purchase within Gray's language?

${ }_{21}^{2}$ Washburn, Real Property (6th ed. I902) secs. 1555, 1556. See also Tiffany, Future Interests (I9I3) 29 L. QUART. REv. 290, 298-30I.

1 (Igig) 28 Yale Law Journal, 8i7.

2 (1885) II5 U. S. 620, 6 Sup. Ct. 209.

'The only other authority cited is a dictum by Judge Henry Wade Rogers in Re Sal"on (I917, C. C. A. 2d) 249 Fed. 300. In this case the court held that a part payment made by an insolvent "takes the debt out of the statute of limitations" so as to make it a provable debt in bankruptcy proceedings, overruling L. Hand, J. (rgi6, S. D. N. Y.) 239 Fed. 413.
} 
the point, nor does it refer to the many criticisms of Campbell v. Holt. ${ }^{4}$ Among other critics of that case, Mr. Justice Holmes, while on the Massachusetts bench, stated that the repeal of the statute even in the case of a debt required "the property of one person to be given to another." In another connection he has attempted a yet more direct analogy between a chose in action and a chattel by assimilating the sale of a horse to the assignment of a money claim. ${ }^{6}$ So far as precedents go, however, while there seems to be a complete unanimity of opinion that the amending statute cannot touch the case of chattels after the original statute has run without running afoul of the constitutional restrictions, ${ }^{7}$ yet the cases are in hopeless conflict as to the effect of such an amendment in the case of a chose in action. ${ }^{8}$

Is there sound basis for a distinction between choses and chattels in this regard? It may be admitted at once that we all sense a difference. The conception of $\mathrm{A}$ in possession of B's horse does not strike us as strange while the same cannot be said of the conception of $C$ in possession of his own debt owed to $D$. But is there a difference here justifying divergent legal results? Are the legal relations of $A$ to $B$ and $B$ to $A$ so unlike those of $C$ to $D$ and $D$ to $C$ as to require $A$ to be treated differently than $C$ and $B$ than $D$ ? It is submitted, on the contrary, that the relations are so nearly identical as logically to require similar rulings in the absence of a compelling reason of policy.

"See Ames, 3 Select Essays (I909) 569 that Campbell v. Holt "stands almost alone" and Chambers v. Gallagher (I9I8) I77 Calif. 704, I7I Pac. 93I, that the contrary holding is supported "by the almost universal course of decisions in the United States," citing decisions from twenty states. It is said that the doctrine of Campbell v. Holt "is undoubtedly technically correct but is opposed to the great weight of authority." Wood, Limitations (4th ed. I9r6) 49.

${ }^{5}$ Danforth v. Groton Water Co. (I90I) 178 Mass. $472,476,59$ N. E. 1033.

- Portuguese-American Bank v. Welles (I9I6) 242 U. S. 7, 37 Sup. Ct. 3 ; and Comment (rgi7) 26 Yale Law Journal, 305. Cf. (Igr5) 24 Yale LAw JoURNAL, 590. We often think of a chose in action as a physical thing, but in reality it is an aggregate of rights, privileges, powers and immunities of the creditor of which the more important correlatives (duties, etc.) are in the debtor. But it must also be remembered that when $A$ owns a physical thing he has only rights, etc. against X, Y, and $Z$. Cf. (I9I9) 28 YALE LAw JournAL, 72I, 730.

${ }^{7}$ See Chapin v. Freeland (1886) r42 Mass. 383,8 N. E. 128; Bryan v. Weens (1856) 29 Ala. 423; Fears, Admr. v. Sykes (1858) 35 Miss. 633. For references to cases collected, see note 8 , infra.

${ }^{8}$ In accord with Campbell v. Holt, see Keller's Admr. v. McHuffman (1879) ${ }_{5}$ W. Va. 64; Orman v. Van Arsdell (Ig04) I2 N. M. 344, 78 Pac. 48. Contra, Chambers v. Gallagher, supra, citing many decisions; Bigelow v. Bemis (186r, Mass.) 2 Allen, 486; Brown v. Parker (I87r) 28 Wis. $2 \mathrm{I}$. The cases are collected in I7 R. C. L. $675 ; 25$ Cyc. 988 ; I2 C. J. 1225 . The situation is complicated when the debtor is a municipality. There the rule appears to be that the amendment is valid since the municipality is not to be treated as an individual but as a branch of the government. Jackson Hill Coal \& Coke Co. v. Board of Comrs. (xç.4) I8r Ind. 335, 104 N. E. 497; State v. Seattle (1910) 57 Wash. 602, 107 $\mathrm{Pa}: 827$ and authorities collected in 23 L. R. A. (N. S.) II88, note. 
We have been shown that courts were loath, until compelled by business necessity, to concede the assignability of a chose in action because there could be no manual tradition of that chose. ${ }^{8}$ It would seem that the same attitude is at bottom responsible for the distinction attempted in these cases. ${ }^{10}$

Even before the statute has run $\mathrm{A}$ has a complex of legal relations in the horse, so that as against all persons except $B$ and those claiming under him, A has all the elements of "ownership." As it was anciently expressed, A had the "property" in the horse while B had only a "right of property."11 This is true whether the original taking was tortious or not. ${ }^{12} \mathrm{~A}$ is, however, under a duty to $\mathrm{B}$ to return the horse if $B$ so elects, while $B$ has a right to a judgment against $A$ for the horse or its value. So $B$ has power with the aid of a court to divest $A$ of such legal interest as $A$ has obtained by his possession and claim of ownership, while $A$ is under a corresponding liability to lose such interest. And while $B$ anciently had no power of transfer to a third party $X$, he may now transfer to $X$ his interest in the horse though it is still in A's possession. ${ }^{13}$ When the statute of limitations has run, A's duty and liability to $B$ cease. And quite properly a statute which thereafter creates a similar duty and liability in $A$ to $B$, is held to deprive A of his "property" without due process of law. C likewise

\footnotetext{
${ }^{\circ} 2$ Pollock \& Maitland, History of English Law (2d ed. 1905) 226; (1917) 26 Yale Law Journal, 305.

${ }^{10} \mathrm{~A}$ distinction is attempted between cases of title by prescription and cases of limitation' affecting the remedy only. "But, probably through failure to, at all times, appreciate the distinction between limitation and prescription, many authorities assume that it is as impossible to revive a lost remedy as to restore a lost right." (I877) 4 CENT. L. Jour. 4I2, approved in (I879) in Am. Dec. 534, note. But why label one case "prescription" and the other "limitation"? $C f$. Cook, The Alienability of Choses in Action, (1916) 29 HARv. L. Rev. 816, 817: "What happens, for example, upon a so-called transfer of title to real property from $A$ to $B$ is, that the rights and other jural relations of $A$ in relation to his fellowmen with respect to the object transferred, are extinguished or divested and that $\mathrm{B}$ becomes invested with similar though not necessarily identical rights and other jural relations. Whether in a given case $A$ and $B$, either singly or acting in cooperation, can do acts to which the law attaches such legal consequences seems to be purely a question of positive law. In this respect it does not seem possible to recognize that the transfer or assignment of a chose in action involves anything fundamentally different from what is involved in the transfer of a chose in possession."

${ }^{11}$ Brian, C. J., Y. B. 6 Hen. VII, 9-4 discussed in Ames, op. cit., 54I, 555. See also Holmes, The Common Law (I88I) 206, 24I; and Bordwell, Property in Chattels (IgI6) 29 HARV. L. REv. 374.

${ }^{12}$ Jefferies v. Great Western $R y$. Co. (1856) 5 El. \& B1. 80; Fletcher v. Cole (1852) 26 Vt. I70; Demick v. Chapman (I8I4, N. Y.) II Johns. 132; Anderson v. Gouldberg (1892) 51 Minn.-294, 53 N. W. 636. Contra, Turley v. Tucker (I860) 6 Mo. 583. See cases collected in Brantly, Personal Property (I89r) sec. I44.

${ }^{23}$ Ames, loc. cit., citing the ancient authorities.
} 
before the running of the statute has almost complete dominion of his various assets, but he is under a duty to pay $D$ and subject to a liability that $D$ with court aid will use his assets to pay the debt. And whereas anciently $D$ had no power of assignment he may now assign to $Y .{ }^{14}$ And here, too, the expiration of the statutory period leaves $C$ owing no duty of payment to $D$ and under no liability to D. ${ }^{15}$ Here, too, how can a duty and liability on C's part be created by act of the legislature without the taking away from one man and the giving to another prohibited by the Federal Constitution as well as by most State constitutions. $^{16}$ The analogy to the situation existing between $\mathrm{A}$ and $\mathrm{B}$ would possibly be clearer if $C$ were not the original debtor to $D$, as if $D$ assigned to $C$ by way of security his claim against $E$ for money due, and $C$ later refused to reassign to $D$ relying on the statute $;^{17}$ but whether one end of the chose is $\mathrm{E}$ or is $\mathrm{C}$, the analogy is so close that the constitutional restriction should apply alike to either case.

The fact that $C$ by new promise or part payment can create a duty similar to that formerly owed to $\mathrm{D}$, has been relied on as justifying the legislative act so far as $C$ is concerned.18 But whether we think of the new promise as "reviving" the old debt or as itself creating an obligation, we must not forget that it is the act of the debtor which is the operative act. ${ }^{19} \mathrm{He}$ exercises his own volition in making the

${ }^{14}$ Ames, loc. cit.; Cook, loc. cit.

${ }^{15}$ The statement in the text is made advisedly, notwithstanding the frequent statements that the debtor has a "moral duty" to pay, sufficient to support a new promise. Legally a duty only exists as a correlative to a right in some one else, which right is enforceable by court action or self help. Cf. Ames, loc. cit.

${ }^{16}$ The provision of the Connecticut Constitution is found in Art. I, sec. 9. Here as elsewhere the use of the label "property" clouds instead of clarifies the discussion. The courts following Campbell $v$. Holt are in effect restricting the term to interests in physical objects, whereas the ordinary usage, as for instance in the settlement of estates, would include interests in choses in action. Does not property mean anything of value to the individual? If so, any legal relation is in effect property. This but emphasizes the point that the term is too inclusive to be of assistance in solving most disputed points. A liberty or privilege to contract where one pleased was recently held to be a "property right." Auburn Draying Co. v. Wardell (1919, N. Y.) 124 N. E. 97.

${ }^{27}$ Yet the Massachusetts Supreme Court held by only a bare majority that the rule as to chattels should be applied to (the privilege of) a seat upon the New York Stock Exchange. Currier v. Studley (1893) I59 Mass. 17, 33 N. E. 709.

${ }^{18}$ Among others, by Justice Miller in Campbell v. Holt, supra.

${ }^{19}$ The correct analysis would seem to be that given in Anson, Contracts (Corbin's ed. 1919) 156, viz., that the operative facts which give rise to the legal relation upon which suit is brought are old debt plus new promise and that without either the right enforceable in the suit does not exist. See also (I9I9) 28 Yale LaW Journal, 817. So L. Hand, J. says that the orthodox theory that the debt is still existing is "a theory full of vicious casuistry," but this did not trouble the upper court which refers to the plea of the statute, as a personal privilege which may be waived. Re Salmon, supra. But one may waive a great many things, even an assertion of complete ownership, by nonaction in a lawsuit. 
new promise, which is quite a different thing from the legislative act, when we come to consider who is doing the act of. "depriving." Nor does the rule of law that a tort cannot be revived by new promise or part payment help. This rule, in itself of doubtful logic and only to be justified upon the theory that it is against public policy to keep alive and give currency to tort claims, does not state a distinction between chattels and choses but between the forms of action, that is, between assumpsit as distinguished from other forms of action. ${ }^{20}$

In view of the varying attitudes of courts towards the statute of limitations we might rest our conclusion on logic alone, on the ground that there was no settled public policy on the question. Courts, while recognizing the value of "statutes of repose" in the abstract, yet have seen only the defendant trying to evade what seems to them a just obligation, on the ground of lapse of time. Yet there is clearly a public policy which recognizes that it is in general the weak case which is delayed, that courts should not be compelled to resurvey old scenes blurred by the passage of time or reopen old sores, in short that there comes a time when bygones must be bygones, "that even the weariest river flows somewhere to the sea." ${ }^{21}$ Now who is to meet with more favor, $A$ who has stolen $B$ 's horse, or $C$ who borrowed money from $D$ ? It seems clear that there are more chances that the possessor of chattels is an active wrongdoer than the one who owes a debt. The latter's opportunities for wrongdoing, other than the mere inaction involved in non-payment, are limited to fraud and duress. Surely the latter should obtain repose by the lapse of time as well as the former. ${ }^{22}$

$\because$ This rule has been applied to debt on bond. Ludlow v. Van Camp (I823) 7 N. J. L. II3. Also to debt on judgment (I9I9) 28 YALE LAW JouRNAL, 8I7. A new promise has been held effective where the tort is waived and suit is brought in assumpsit. Moses v. Taylor (1888; Dist. Col.) 6 Mackey, 255; contra, Nelson v. Patterson (Ig07) 229 I1l. 240, 82 N. E. 229. The reason given for the rule is that a new promise cannot "amount to a new tort." Goodwyn v. Goodwyn (I854) I6 Ga. I14, II7. It has been said that no tort claim is assignable. Gardiner v. Adans (I834, N. Y.) I2 Wend. 297. But the general rule is that claims for injuries except those for tort to the person are assignable. Comegys v. Vasse (I828, U. S.) I Pet. I93, 213; Rice v. Stone (1861, Mass.) I Allen, 566. If old debt phis new promise will create a legal obligation, so should old tort plus new promise, except where public policy intervenes, i. e., except in cases of claims for tort to the person. Cf. Patterson v. Breitag (1893) 88 Iowa, 418, $55 \mathrm{~N}$. W. 86, declining to enforce a note and mortgage given to satisfy a barred claim for criminal conversation.

${ }^{2}$ Cf. Justice Story in Bell v. Morrison (1828, U.'S.) I Pet. 351, 360, 362. In Koyl v. Lay (Ig16) I94 Mo. App. 29I, I87 S. W. 279, the court criticised plaintiffs for waiting until all the other witnesses were dead. Statutes of limitation themselves do deprive one of property, but they had met the approval of the general community before the time of written constitutions and are hence due process of law. Cooley, Constitutional Limitations (7th ed. I903) 520.

${ }_{22} \mathrm{C}$ appears to have an advantage over $\mathrm{A}$ as to the time when the statute starts to run, if A's original possession of the chattel was not tortious, since the statute does not run until the possession is adverse. Smith v. Townes's Admr. 
There is, however, one consideration that at first sight seems important, namely, the interest of the innocent third person. Should not $M$ who has purchased the horse of $A$ be protected? Yes, though if this protection was of chief importance we ought to protect $M$ without reference to some arbitrary length of time which has passed since A had violated a duty to $B$. $M$ is relying on $A$ 's possession rather than on the passage of time since A's breach of duty. But at most this is simply an added argument for the holding as to chattels and is not itself an argument against the application of the same rule to choses. And yet does $M$ deserve protection more than $N$ who is dealing with C on the basis of the latter's present credit? Though N's reliance upon the present situation is based upon general credit rather than upon the possession of specific articles, yet at bottom N's position appears similar to M's and from the standpoint of public policy he should be accorded like protection to that accorded $M$.

This is not the place to discuss in detail the conflict of laws as affecting the running of the statute further than to suggest that here, too, chattels and choses should be treated alike. And it would seem that the situation discloses no real difficulty. D may have a right against $\mathrm{C}$ enforcible in one state and a similar right enforcible during a different period in another state. Although this is often pointed to as demonstrating that the statute affects only the remedy it means no more than that $D$ has more than one road to reach his goal. Yet after time has closed those roads and $C$ no longer owes a duty of payment to $D, C$ 's privilege and immunity as respects $D$ should be and according to the better reasoned decisions are respected no matter what state $C$ happens to be in. ${ }^{23}$

In criticising the ground of the decision in Gilbert $v$. Selleck the writer does not assert that the decision may be incorrect. For there an action had been pending in the Federal Court and was finally dismissed in that court for lack of jurisdiction. The amendments passed by the legislature pending that suit provided that where an action had been dismissed in the Federal Court for lack of jurisdiction suit might be started in the State Court within one year after such dismissal. ${ }^{24}$

(I8I4, Va.) 4 Munf. I9r. But neither does it run in C's case until there is a breach of duty, which is apparently all that "adverse" holding means. Under most statutes, also, the time does not run while the cause of action is concealed, or as it is sometimes put, while the adverse holding is not open and notorious. Gatlin v. Vant (I906) 6 Indian Terr. 254, 9r S. W. 35 ; State ex rel. McClure v. Northrop (1919, Conn.) ro8 Atl.

${ }^{23}$ Shelby v. Guy (I826, U. S.) Ir Wheat. 361, 37I, 6 L. ed. 495; Brown v. Parker (I87I) 28 Wis. 2I, 27; Fear's Admr. v. Sykes (I858) 35 Miss. 633 . Cf. Comment (igig) 28 Yale Law Journal, 492.

${ }^{24}$ To make assurance trebly certain, the legislature passed three amendments to this effect, one each in I9I3, I9I5 and 19I7. During each of these sessions plaintiff's attorney was a member of the legislature and of the particular committee which had the amendments in charge. Defendants were justified in admitting that there was no opportunity for the operation of the rule that, where possible, statutes are not to be construed as operating retroactively. 
Actually the suit in question was started before the final decision in the federal suit. Now it is well settled that before the statute has run the legislature may extend the time ${ }^{25}$ and also that where suit is brought before the statute has run amendments may later be made, such as increasing the damages claimed or changing the mere form of action. $^{2 B}$ In effect it means that A's and C's duty and liability exist so long as there is a suit pending, and that while such duty and liability exist they may be extended by the legislature, which is obviously a situation quite other than the recreation of a duty and liability after they have ceased to exist. ${ }^{27}$ It is but little if any stretch to apply the amendment theory to the transfer of a suit from one court to another. ${ }^{28}$ But such application should be made alike in the case of chattels as well as choses between which there is for limitation purposes no real distinction.

C. E. C.

THE DOCTRINE OF MERGER AS APPLIED TO COMMERCIAL TRUSTS

The modern commercial or real estate trust, so frequently the subject of subtle legal refinements, yet definitely sanctioned by law and extensively employed in practice, has recently become exposed to a new complication from a most unexpected source, the ancient and abstract doctrine of merger.

In the case of Cunningham $v$. Bright, ${ }^{1}$ the sole trustee of a real estate trust acquired by indorsement all of the transferable shares representing the equitable interest in the trust. Subsequently the real estate standing in his name as trustee was attached by his personal creditor. The attachment was upheld, notwithstanding the ostensible trust, on three independent grounds. Two of these grounds ${ }^{2}$ were manifestly sufficient and do not now concern us. The third was that

${ }^{2}$ Davis v. Mills (1903) x94 U. S. 45I, 457, 24 Sup. Ct. 692; Danforth v. Groton Water Co. (I90I) I78 Mass. 472, 59 N. E. I033.

${ }^{2}$ Moses v. Tayler (1880, Dist. Col.) 6 Mackey, 255; Frederichsen v. Renara (Igr8) 247 U. S. 207,38 Sup. Ct. 450 . See Comment (rgi8) 27 Yale Law Journal, I053; (IgI9) 28 YALE LAW JourNal, 693. The cases are collected in 3 L. R. A. (N. S.) 259.

${ }^{2}$ See discussion of Mr. Justice Holmes in Danforth v. Groton Water Co., supra. In Dunbar v. R. R. (Ig02) I8I Mass. 383,63 N. E. 9I6, criticised in (Ig02) I6 HARv. L. Rev., he goes still further. Cf. Fleming v. Railroad (Igor) 128 N. C. 80,38 S. E. 253 .

${ }^{2}$ In the present case the federal suit had dragged on for eight years and for three years more on appeal, and the plaintiff may therefore be entitled to little sympathy for such delay. Yet where the plaintiff has instituted suit before the statute has run, the delay is partly the court's fault and another court is not justified in penalizing the plaintiff for delays which the first court could control.

${ }^{1}$ (I9I7) 228 Mass. 385 , Ir7 N. E. 909.

airst, the trust was merely a device for the evasion of attachments; second, the equitable interest, as entitling the debtor to a present conveyance of the legal estate, was itself subject to attachment under Mass. Rev. Law, 1902, ch. I78, sec. I. 